\title{
Clinical Observations on Infliximab Treatment of Infantile Onset Takayasu Arteritis
}

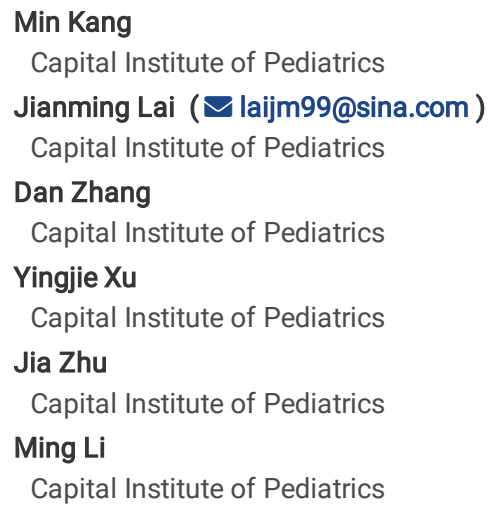




\section{Abstract \\ Background}

To study short-term clinical effectiveness and safety of infliximab (IFX) treatment of infants with Takayasu arteritis (TA).

\section{Methods}

We investigated the therapeutic effectiveness of IFX in 10 infantile TA in a retrospective case series. Evaluation included assessment of clinical symptoms, laboratory testing, and vascular imaging.

\section{Results}

Fever was the presenting symptom for 8 of 10 infants with TA. In the acute episode, leucocyte and inflammatory indices increased significantly. Vascular imaging showed that the most commonly-involved arteries were carotid arteries, abdominal aortas, and coronary arteries ( 9 cases, $90 \%$ ). Two weeks after IFX treatment, leukocyte and platelet counts decreased, and hemoglobin levels increased. There were significant clinical differences 6 weeks after treatment compared with before treatment $(p<0.05)$. Inflammatory indices decreased significantly 2 weeks after starting IFX treatment compared with before treatment $(p<0.05)$. Vascular lesions began to recover within 1.5-3 months of initiating IFX therapy, and the involved vessels significantly recovered within 13 months. Some arteries remained stenotic, intimal thickening and uneven lumen wall thickness.

\section{Conclusions}

TA is rare in infancy. Fever may be the main manifestation of illness, often accompanied by significantly increased inflammatory indices. Early use of IFX appears to be effective, significantly decreasing inflammatory markers and improving clinical features, leading to partial remission of vascular lesions and sustain remissions for some infants. Use of IFX reduced or eliminated need for glucocorticoids. IFX has a reasonable safety profile and does not appear to affect normal growth and development of infants with TA.

\section{Background}

Takayasu's arteritis (TA) is a systemic vasculitis involving the aorta and its main branches that causes chronic inflammation of the artery, leading to stenosis or even occlusion of the arterial lumen. It occurs most frequently in women and is rare in infancy and childhood. However, TA does occur in infancy, generally with multi-vessel involvement and severe systemic inflammation, and carrying a bad prognosis. Glucocorticoids and immunosuppressive agents are currently the drugs of choice for treatment of TA, but their side effects in infants are undesirable and may be unacceptable. Recent clinical trials have demonstrated the efficacy of IFX in both adult and childhood TA[1-4]. However, to our knowledge, there are no published studies assessing effectiveness of IFX in infantile onset TA. We searched four mainstream medical databases - PubMed, China Network Knowledge Infrastructure (CNKI), Wan-Fang, and China Science and Technology Journal Database (CSTJ) - for studies published through April 30, 2021 using the search words, Takayasu arteritis, infant, children, biologic agent, and infliximab. Our search retrieved one relevant citation - a single case report from our department in the children's hospital affiliated to Capital Institute of Pediatrics[5]. We now report 10 cases of infantile onset TA that were treated with IFX during and after 2016 and describe effectiveness and safety of IFX in these cases.

\section{Methods Patients}

Study inclusion criteria were that subjects must meet diagnostic criteria of children's TA [6][5] with onset during the first year of life. Potential subjects were excluded from consideration of IFX treatment if they had evidence of acute or chronic active viral, mycoplasma, or fungal infections. Potential subjects were tested for cytomegalovirus nucleic acid, EB virus nucleic acid, Legionella pneumophila serum type I IgM antibody, Chlamydia pneumoniae IgM antibody, adenovirus IgM antibody, respiratory syncytial virus IgM antibody, influenza A and B virus antibody, and parainfluenza virus IgM antibody, and with bacterial blood cultures. The interferon release test for tuberculosis was used to exclude active tuberculosis; screening for hepatitis B virus antibodies was used to exclude hepatitis B virus infection. We tested immune function and conducted whole exon genome sequencing to exclude potential subjects with congenital immune deficiencies.

Between July 2016 and August 2020, ten infants were diagnosed with TA in our hospital, admitted for treatment, met our inclusion criteria, and did not have any exclusion criteria. These ten infants formed the study group.

\section{Ethical review}

The study was approved by the Ethical Committee of Children's Hospital Capital Institute of Pediatrics; guardians provided written, informed consent for their infants.

\section{Treatment}


Infliximab, 5-6mg/kg, was given intravenously at 0, 2, 6, 14, 22 and 30 weeks and, depending on the apparent effect of the treatment, additional IFX injections were given at 8-week intervals. At the beginning of treatment, glucocorticoid (GC) and immunosuppressive therapy was continued in 5 patients; another 5 patients were treated with IFX alone and their GC dose was adjusted during treatment in accordance with the infant's condition.

\section{Clinical indicators}

We abstracted infants' medical records for data on age, gender, medical history, physical examination, laboratory tests, cardiac ultrasound, vascular ultrasound, chest and abdomen enhanced CT, and CT angiography(CTA). We recorded time-varying clinical data on temperature, blood pressure, routine blood tests, inflammatory indices, cytokines, and immunity. Vascular ultrasound and/or CTA was used to evaluate progression of vascular lesions. We recorded GC and immunosuppressive agent doses administered before and after IFX was started.

\section{Safety evaluation and follow-up}

The infants were followed up every 1 to 3 months for 8 to 64 months to record their symptoms, liver and kidney functioning, and signs of infection. We conducted follow-up assessments in the hospital, during outpatient visits, and by telephone. We obtained data on height, weight, clinical symptoms, and treatment. No cases were lost to follow-up.

\section{Statistical analysis}

Continuous data are presented as means with standard deviations or ranges. Means were compared by independent-sample $t$ tests. A $p$ value $<0.05$ was considered statistically significant.

\section{Results}

\section{Baseline characteristics}

Ten infants qualified for the study - two boys and eight girls. The ages of onset of their TA ranged from 1 month, 17 days to 5 months, 7 days. At the time of diagnosis, durations of illness were less than 1 month in seven cases and 1-3 months in the other three cases.

\section{Clinical manifestation and Medication before IFX}

The most common clinical manifestation was fever in 9 cases $(90 \%)$. Six $(60 \%)$ infants had hypertension; three $(30 \%)$ had weak or no detectable pulse; two (20\%) had vomiting, and one had transient low-grade fever twice during the illness; no infants had rashes or vascular bruits (Table 1).

The most commonly-involved vessels were carotid arteries, abdominal aortas, and coronary arteries ( 9 cases, $90 \%$ ); Thoracic aortas and subclavian aortas (8 cases, $80 \%$ ), renal arteries (7 cases, 70\%), axillary arteries, pulmonary arteries and descending aortas ( 6 cases, $60 \%)$, and superior mesenteric arteries (4 cases, 40\%) (Table 2).

Five of the infants were treated with IFX alone. Five infants had been treated with GC $(1-1.5 \mathrm{mg} / \mathrm{kg} /$ day) prior to receiving IFX, which was started because their inflammation indexes did not decrease and/or vascular imaging showed extensive involvement or no improvement. Cases 6, 7, and 8 had been treated with GC ( $1 \mathrm{mg} / \mathrm{kg} /$ day) prior to receiving IFX; their inflammation indexes decreased slightly. After combination therapy with IFX, the GC doses were decreased quickly at first, then gradually, discontinuing at 12 weeks into therapy in 2 cases and 16 weeks in the other case. The Case 9 infant had been treated with prednisone $(1.5 \mathrm{mg} / \mathrm{kg} / \mathrm{day})$. Temperature and inflammatory indexes quickly returned to normal. After oral administration of prednisone for 4 months, the dose was reduced to $5 \mathrm{mg} /$ day for 3 months and was combined with methotrexate (MTX) for 4 more months. However, CTA showed that the celiac trunk artery and the left iliac artery were thinner than before, suggesting that the vascular lesion was worsening. The infant had slow growth and development. IFX therapy was added, and the prednisone was reduced and then discontinued in 2 weeks. For the Case $10 \mathrm{infant}$, oral GC (1 mg/kg/day) was used in combination with antiinterleukin 6 receptor antibody (tocilizumab) $(12 \mathrm{mg} / \mathrm{kg}$, every two weeks) for 3 months. The coronary arteries showed significant improvement, but CTA showed no more improvement than as seen at the beginning of the disease; therapy was changed to IFX (Table 2). 
Table 1

Clinical characteristics of 10 infants with Takayasu arteritis

\begin{tabular}{|lllllll|}
\hline Case & Fever & Hypertension & Vomiting & Rash & Pulselessness & Vascular bruit \\
\hline 1 & Y & Y & Y & N & Y & N \\
\hline 2 & Y & N & N & N & N & N \\
3 & Y & Y & N & N & N & N \\
4 & Y & Y & N & N & N & N \\
\hline 5 & Y & Y & N & N & Y & N \\
6 & Y & Y & N & N & N & N \\
7 & Y & N & N & N & N & N \\
\hline 8 & Y & Y & N & N & N & N \\
9 & Y & N & N & N & N & N \\
\hline 10 & N & N & Y & N & Y & \\
\hline
\end{tabular}


Table 2

Involved arteries before and after treatment, and treatment regimens in 10 infants with Takayasu arteritis

\begin{tabular}{|c|c|c|c|c|c|c|c|c|c|c|c|c|}
\hline Case & Time & $\begin{array}{l}\text { Carotid } \\
\text { artery } \\
\text { L/R }\end{array}$ & $\begin{array}{l}\text { Subclavian } \\
\text { artery } \\
\text { L/R }\end{array}$ & $\begin{array}{l}\text { Coronary } \\
\text { artery } \\
\text { L/R }\end{array}$ & $\begin{array}{l}\text { Coronary } \\
\text { artery } \\
\text { aneurysm } \\
\text { L/R }\end{array}$ & $\begin{array}{l}\text { Brachial } \\
\text { artery } \\
\text { L/R }\end{array}$ & $\begin{array}{l}\text { Axillary } \\
\text { artery } \\
\text { L/R }\end{array}$ & $\begin{array}{l}\text { Pulmonary } \\
\text { artery }\end{array}$ & $\begin{array}{l}\text { Descending } \\
\text { aorta }\end{array}$ & $\begin{array}{l}\text { Thoracic } \\
\text { aorta }\end{array}$ & $\begin{array}{l}\text { Abdominal } \\
\text { aorta }\end{array}$ & $\begin{array}{l}\text { Ren: } \\
\text { arter } \\
\text { L/R }\end{array}$ \\
\hline \multirow[t]{9}{*}{1} & Before & $+/+$ & $+/+$ & $+/+$ & $+/+$ & $+/+$ & $+/+$ & + & + & + & + & $+/+$ \\
\hline & 4 months & $+/+$ & $+/+$ & $+/+$ & $+/+$ & $+/+$ & $+/+$ & + & + & + & + & $+/+$ \\
\hline & 8 months & $+/+$ & $+/+$ & $+/+$ & $+/+$ & $-1-$ & $+/+$ & + & + & + & + & $+/+$ \\
\hline & $\begin{array}{l}14 \\
\text { months }\end{array}$ & $+/+$ & $+/+$ & $+/+$ & $+/+$ & $-1-$ & $-1-$ & + & + & + & + & $+/-$ \\
\hline & $\begin{array}{l}20 \\
\text { months }\end{array}$ & $+/+$ & $-1-$ & $+/+$ & $-/+$ & $-1-$ & $-1-$ & - & + & + & + & $+/-$ \\
\hline & $\begin{array}{l}26 \\
\text { months }\end{array}$ & $-1-$ & $-1-$ & $+/+$ & $-/+$ & $-1-$ & $-/-$ & - & - & + & + & $+/-$ \\
\hline & $\begin{array}{l}38 \\
\text { months }\end{array}$ & $-1-$ & $-1-$ & $+/+$ & $-/+$ & $-1-$ & $-1-$ & - & - & + & + & $-/-$ \\
\hline & $\begin{array}{l}44 \\
\text { months }\end{array}$ & $-/-$ & $-1-$ & $+/+$ & $-/+$ & $-/-$ & $-/-$ & - & - & + & + & $-1-$ \\
\hline & $\begin{array}{l}20 \\
\text { months } \\
\text { after } \\
\text { stopping } \\
\text { IFX }\end{array}$ & $-/-$ & $-/-$ & $+/+$ & $-/+$ & $-1-$ & $-1-$ & - & - & + & + & $-1-$ \\
\hline \multirow[t]{5}{*}{2} & Before & $+/+$ & $+/+$ & $+/+$ & $-1-$ & $-1-$ & $+/+$ & + & - & - & - & $-1-$ \\
\hline & 4 months & $+/+$ & $+/-$ & $+/+$ & $-/-$ & $-1-$ & $+/+$ & + & - & - & - & $-/-$ \\
\hline & 8 months & $+/+$ & $-1-$ & $+/-$ & $-/-$ & $-1-$ & $-/-$ & - & - & - & - & $-1-$ \\
\hline & $\begin{array}{l}14 \\
\text { months }\end{array}$ & $+/-$ & $-1-$ & $-1-$ & $-1-$ & $-1-$ & $-/-$ & - & - & - & - & $-/-$ \\
\hline & $\begin{array}{l}20 \\
\text { months }\end{array}$ & $-/-$ & $-1-$ & $-1-$ & $-1-$ & $-1-$ & $-/-$ & - & - & - & - & $-1-$ \\
\hline \multirow[t]{4}{*}{3} & Before & $+/+$ & $+/+$ & $+/+$ & $+/+$ & $-1-$ & $-1-$ & - & - & - & + & $+/-$ \\
\hline & 4 months & $-/-$ & $+/+$ & $+/+$ & $-/+$ & $-1-$ & $-/-$ & - & - & - & + & $+/-$ \\
\hline & 8 months & $-/-$ & $-1-$ & $+/-$ & $-/-$ & $-1-$ & $-/-$ & - & - & - & - & $-1-$ \\
\hline & $\begin{array}{l}25 \\
\text { months } \\
\text { after } \\
\text { stopping } \\
\text { IFX }\end{array}$ & $-1-$ & $-1-$ & $+/-$ & $-1-$ & $-1-$ & $-/-$ & - & - & - & - & $-1-$ \\
\hline \multirow[t]{4}{*}{4} & Before & $-1-$ & $-1-$ & $+/+$ & $+/+$ & $-1-$ & $-/-$ & + & - & + & + & $+/-$ \\
\hline & 4 months & $-/-$ & $-1-$ & $+/+$ & $-1-$ & $-1-$ & $-1-$ & + & - & + & + & $+/-$ \\
\hline & 8 months & $-1-$ & $-1-$ & $+/+$ & $-1-$ & $-1-$ & $-/-$ & - & - & + & + & $-1-$ \\
\hline & $\begin{array}{l}10 \\
\text { months }\end{array}$ & $-1-$ & $-/-$ & $-1-$ & $-1-$ & $-1-$ & $-1-$ & - & - & - & + & $-1-$ \\
\hline \multirow[t]{6}{*}{5} & Before & $+/+$ & $+/+$ & $+/+$ & - & $-1-$ & $+/+$ & + & + & + & + & $-1-$ \\
\hline & 4 months & $+/+$ & $+/+$ & $+/+$ & - & $-/-$ & $+/+$ & + & + & + & + & $-1-$ \\
\hline & 8 months & $+/-$ & $-/-$ & $+/+$ & - & $-1-$ & $-1-$ & - & - & + & + & $-1-$ \\
\hline & $\begin{array}{l}14 \\
\text { months }\end{array}$ & $-1-$ & $-1-$ & $-/-$ & - & $-1-$ & $-/-$ & - & - & + & - & $-1-$ \\
\hline & 20 months & $-/-$ & $-1-$ & $-/-$ & - & $-1-$ & $-1-$ & - & - & - & - & $-1-$ \\
\hline & 22 months & $-/-$ & $-/-$ & $-1-$ & - & $-1-$ & $-1-$ & - & - & - & - & $-/-$ \\
\hline \multirow[t]{3}{*}{6} & Before & $+/+$ & $+/+$ & $+/+$ & - & $+/+$ & $+/+$ & + & + & + & + & $-/+$ \\
\hline & 4 months & $+/+$ & $+/+$ & $+/+$ & - & $+/+$ & $+/+$ & + & + & + & + & $-/+$ \\
\hline & 8 months & $+/+$ & $+/+$ & $-1-$ & - & $-1-$ & $+/+$ & - & + & + & + & $-1-$ \\
\hline
\end{tabular}

Note: + means involved, - means not involved or recovered; IFX=infliximab, GC=glucocorticoids, MTX=methotrexate, TCZ=tocilizumab, L=Left, R=Right. 


\begin{tabular}{|c|c|c|c|c|c|c|c|c|c|c|c|c|}
\hline Case & Time & $\begin{array}{l}\text { Carotid } \\
\text { artery } \\
\text { L/R }\end{array}$ & $\begin{array}{l}\text { Subclavian } \\
\text { artery } \\
\text { L/R }\end{array}$ & $\begin{array}{l}\text { Coronary } \\
\text { artery } \\
\text { L/R }\end{array}$ & $\begin{array}{l}\text { Coronary } \\
\text { artery } \\
\text { aneurysm } \\
\text { L/R }\end{array}$ & $\begin{array}{l}\text { Brachial } \\
\text { artery } \\
\text { L/R }\end{array}$ & $\begin{array}{l}\text { Axillary } \\
\text { artery } \\
\text { L/R }\end{array}$ & $\begin{array}{l}\text { Pulmonary } \\
\text { artery }\end{array}$ & $\begin{array}{l}\text { Descending } \\
\text { aorta }\end{array}$ & $\begin{array}{l}\text { Thoracic } \\
\text { aorta }\end{array}$ & $\begin{array}{l}\text { Abdominal } \\
\text { aorta }\end{array}$ & $\begin{array}{l}\text { Rene } \\
\text { arter } \\
\text { L/R }\end{array}$ \\
\hline & $\begin{array}{l}14 \\
\text { months }\end{array}$ & $-/-$ & $+/+$ & $-1-$ & - & $-1-$ & $+/+$ & - & + & + & - & $-/-$ \\
\hline & $\begin{array}{l}20 \\
\text { months }\end{array}$ & $-1-$ & $-1-$ & $-1-$ & - & $-1-$ & $+/+$ & - & + & + & - & $-/-$ \\
\hline & $\begin{array}{l}22 \\
\text { months }\end{array}$ & $-/-$ & $-/-$ & $-1-$ & - & $-1-$ & $+/+$ & - & + & + & - & $-/-$ \\
\hline \multirow[t]{5}{*}{7} & Before & $+/+$ & $+/+$ & $+/+$ & $+/+$ & $-/-$ & $+/+$ & - & - & + & + & $+/+$ \\
\hline & 4 months & $+/+$ & $+/+$ & $+/+$ & $+/+$ & $-1-$ & $+/+$ & - & - & + & + & $+/+$ \\
\hline & 8 months & $-1-$ & $-1-$ & $+/+$ & $-1-$ & $-1-$ & $+/+$ & - & - & + & + & $-1-$ \\
\hline & $\begin{array}{l}14 \\
\text { months }\end{array}$ & $-1-$ & $-1-$ & $+/+$ & $-/-$ & $-1-$ & $-/-$ & - & - & + & + & $-1-$ \\
\hline & $\begin{array}{l}20 \\
\text { months }\end{array}$ & $-1-$ & $-1-$ & $+/+$ & $-/-$ & $-1-$ & $-1-$ & - & - & + & + & $-/-$ \\
\hline \multirow[t]{5}{*}{8} & Before & $+/+$ & $+/+$ & $+/+$ & $-1-$ & $-1-$ & $+/+$ & - & + & + & + & $+/+$ \\
\hline & 4 months & $+/+$ & $+/+$ & $+/+$ & $-1-$ & $-1-$ & $+/+$ & - & + & + & + & $-1-$ \\
\hline & 8 months & $+/-$ & $+/+$ & $+/+$ & $-/-$ & $-1-$ & $-/-$ & - & + & - & + & $-1-$ \\
\hline & $\begin{array}{l}12 \\
\text { months }\end{array}$ & $-1-$ & $-/+$ & $-1-$ & $-1-$ & $-1-$ & $-1-$ & - & - & - & - & $-/-$ \\
\hline & $\begin{array}{l}14 \\
\text { months } \\
\text { after } \\
\text { stopping } \\
\text { IFX }\end{array}$ & $-1-$ & $-/+$ & $-1-$ & $-1-$ & $-1-$ & $-/-$ & - & - & - & - & $-/-$ \\
\hline \multirow[t]{3}{*}{9} & Before & $+/+$ & $-1-$ & $-1-$ & - & $-1-$ & $-/-$ & + & + & + & + & $-1-$ \\
\hline & 4 months & $+/+$ & $-1-$ & $-1-$ & - & $-1-$ & $-/-$ & + & + & + & + & $-/-$ \\
\hline & 8 months & $+/-$ & $-1-$ & $-1-$ & - & $-1-$ & $-/-$ & - & + & + & + & $-1-$ \\
\hline \multirow[t]{6}{*}{10} & Before & $+/-$ & $+/-$ & $+/+$ & $+/+$ & $-1-$ & $-/-$ & - & + & + & + & $+/-$ \\
\hline & $\begin{array}{l}3 \text { months } \\
\text { of GC } \\
+\mathrm{TCZ}\end{array}$ & $+/-$ & $+/-$ & $+/+$ & $-/-$ & $-1-$ & $-/-$ & - & + & + & - & $-1-$ \\
\hline & 4 months & $+/-$ & $+/-$ & $+/+$ & $-/-$ & $-1-$ & $-/-$ & - & + & + & - & $-1-$ \\
\hline & 8 months & $-1-$ & $-/-$ & $+/-$ & $-1-$ & $-1-$ & $-/-$ & - & + & + & - & $-1-$ \\
\hline & $\begin{array}{l}12 \\
\text { months }\end{array}$ & $-/-$ & $-1-$ & $+/-$ & $-/-$ & $-1-$ & $-/-$ & - & + & - & - & $-1-$ \\
\hline & $\begin{array}{l}4 \text { months } \\
\text { after } \\
\text { stopping } \\
\text { IFX }\end{array}$ & $-1-$ & $-1-$ & $-1-$ & $-1-$ & $-1-$ & $-1-$ & - & + & - & - & $-/-$ \\
\hline
\end{tabular}

Note: + means involved, - means not involved or recovered; IFX=infliximab, GC=glucocorticoids, MTX=methotrexate, TCZ=tocilizumab, L=Left, R=Right.

\section{Clinical manifestations and outcomes after IFX treatment}

In the five patients treated with IFX alone, fever was controlled in 1-2 days. Blood pressures decreased to normal ranges after 3-8 months of IFX, without use of antihypertensives. Three infants continued to have weak pulses that did not improve with IFX.

Coronary arteries were reexamined one and a half months after initiation of IFX; coronary artery examinations and vascular imaging were performed at 4,8 , 14, 20, 26 and 32 months. After one and a half months of treatment, coronary ultrasound showed that the diameters of affected coronary arteries decreased. After four months, vascular ultrasound showed that the average thickness of affected arterial walls decreased, the number of diseased vessels decreased, and vessel wall thickening decreased. After 8 months, the affected vessels improved to a great extent and in some cases returned to normal. With continuation of treatment, vascular wall lesions ultimately improved, but some complications remained. Affected artery lumens were uneven; there was some vascular dilatation and stenosis, especially of the thoracic and abdominal aorta. Subjects did not worsen, and vascular narrowing showed some improvement (Table 2). 
Growth and development of nine infants with TA was similar to age-matched healthy infants after 8-64 months of follow-up. In one infant treated with GC combined with MTX, height was less than the 3rd percentile for same-age healthy infants. At eight months, height was at the 5th percentile.

\section{Laboratory tests}

At onset of TA, leukocyte and platelet counts were high, hemoglobin was low, and inflammatory indexes were high, suggesting that all ten cases were in the active, acute stage. Leukocytes and platelet counts decreased, and hemoglobin increased after two weeks of IFX treatment. At six weeks, these laboratory values improved compared with values before treatment $(p<0.05)$; Two weeks after IFX treatment started, the inflammatory indexes of $\mathrm{C}$-reactive protein and erythrocyte sedimentation rate decreased significantly compared with before treatment $(p<0.05)$ (Table 3$)$.

Table 3

Changes in laboratory values

\begin{tabular}{|c|c|c|c|c|c|c|}
\hline \multirow[t]{2}{*}{ Treatment } & \multirow[t]{2}{*}{ Period } & \multicolumn{5}{|c|}{ Laboratory tests } \\
\hline & & WBC & HGB & PLT & CRP & ESR \\
\hline \multirow[t]{4}{*}{ IFX } & Before & $19.31 \pm 3.22$ & $95.8 \pm 11.26$ & $828.6 \pm 192.94$ & $66.8 \pm 39.32$ & $79 \pm 40.51$ \\
\hline & After 2 weeks & $14.53 \pm 1.82$ & $111.8 \pm 7.53^{\star}$ & $441.6 \pm 151.15$ & $3.66 \pm 2.36$ & $17.6 \pm 13.15$ \\
\hline & $t$ value & 2.89 & 2.64 & 3.53 & 3.58 & 3.22 \\
\hline & $p$ & 0.02 & 0.03 & 0.01 & 0.01 & 0.01 \\
\hline \multirow[t]{4}{*}{$\mathrm{IFX}+\mathrm{GC}$} & Before & $16.07 \pm 5.52$ & $93.4 \pm 6.62$ & $664.4 \pm 193.16$ & $101.96 \pm 33.71$ & $67.8 \pm 40.88$ \\
\hline & After 2 weeks & $10.77 \pm 4.49$ & $119.2 \pm 13.95^{\star}$ & $386 \pm 91.59$ & $14.88 \pm 11.33$ & $21.2 \pm 13.97$ \\
\hline & $t$ value & 1.67 & 3.74 & 7.5 & 5.48 & 2.41 \\
\hline & $p$ & 0.13 & 0.01 & 0.01 & 0.01 & 0.04 \\
\hline
\end{tabular}

Note: *-after 6 weeks, WBC-leukocyte, HGB- hemoglobin, PLT-platelet, CRP-C-reactive protein, ESR-erythrocyte sedimentation rate, IFX=infliximab, $\mathrm{GC}=$ glucocorticoids.

\section{Safety evaluation and follow-up}

The Case10 infant had a red rash on her face and chest during the 4th and 7th infusion of IFX. The rash gradually subsided when the infusion was stopped, and no adverse events occurred when the infusion was resumed. During the first 15 minutes of her 8th infusion, she had vomiting and was pale, although with normal blood pressure. Vomiting stopped when the infusion was stopped. In addition, she had a red rash that subsided 30 minutes after oral antiallergic drugs were given. It was considered to be an allergic reaction, and the infusion was not restarted. No other infants had adverse reactions. No cases of severe infection or pneumonia were seen during treatment or follow-up. In Case 1, IFX was used for 44 months (24 infusions total) and then MTX was added. In Cases 2 and 7, IFX was used for 20 months (12 infusions total for each infant), and MTX was added in case 7 during IFX treatment. In Cases 3 , IFX was used for 8 months ( 6 infusions total). In Case 4, IFX was used for 10 months ( 7 infusions total). In Case 5 and 6 , IFX was used for 22 months ( 13 infusions total for each infant), and MTX was added in case 6 . In Cases 8 and 10, IFX was used for 12 months (8 infusions total for each infant), and MTX was added in case 10. In Case 9, IFX was used for 8 months ( 6 infusions). One to three months after starting IFX treatment, inflammatory indexes and hematological tests of all cases returned to normal. Routine hematologic tests and inflammatory indexes remained normal during follow-up.

\section{Discussion}

Takayasu arteritis usually occurs among females 40 years of age and younger, including children, but is rare during infancy. Because clinical manifestations are not specific, TA is difficult to diagnose. We studied 10 infants diagnosed with TA, most of whom were initially diagnosed with an infection or incomplete Kawasaki disease and were treated with anti-infective therapy and gamma globulin. However, with uncontrollable fever and inflammation and observation of coronary artery involvement, TA was considered as a diagnosis in these cases and was confirmed with further laboratory testing and vascular imaging. There are few reports of treatment results in the scientific literature, especially treatment of infantile TA, which is rare globally, making our treatment results useful for clinicians and researchers.

TA is usually chronic with either a linear course or a remitting-relapsing course. The inflammatory process causes thickening of arteries with narrowing or occlusion of the lumen. Glucocorticoids are the mainstay of treatment. Because glucocorticoids alone do not always achieve and maintain remission, approximately half of TA patients require immunosuppressive agents[4,6-9]. In contrast with childhood TA, vascular involvement is highly variable in infants and carries a worse prognosis, requiring high-dose, long-duration GC use. Unfortunately, glucocorticoids significantly affect growth and development of infants - a side effect that cannot be ignored. For example, in our study, one infant was treated with glucocorticoids for 7 months, affecting growth and development and necessitating consideration of alternative therapy.

Clinical manifestations of TA are nonspecific in infants and children. Fever and inflammation are the most common manifestations; the abdominal aorta is the most commonly involved vessel[10-16]. In our series, eight (80\%) cases had fever as the first symptom and most prominent clinical manifestation. Laboratory analyses showed increased leukocytes and inflammatory indexes. Vascular imaging showed that large and medium arteries were involved. The most commonly-involved arteries were carotid arteries, abdominal aortas and coronary arteries (9 cases, $90 \%)$. Thoracic aortas and subclavian aortas (8 cases, $80 \%$ ), renal arteries (7 cases, $70 \%)$, axillary arteries, pulmonary arteries and descending aortas (6 cases, $60 \%)$, and superior mesenteric arteries (4 cases, 
40\%) were also commonly involved. All 10 infants were in active disease states at the time of diagnosis, with widespread vascular involvement, suggesting that the infants' conditions were serious and had poor prognoses.

Tumor necrosis factor alpha (TNF-a) is implicated in TA inflammation. IFX is a TNF-a inhibitor that has direct cytotoxicity and induces apoptosis of immune cells. IFX is reported to have significant effectiveness in refractory TA that is resistant to glucocorticoids and immunosuppressants[8, 9, 17-20]. Our observations showed that IFX is also effective for treatment of TA in infants. Five of our cases were treated with IFX alone and five were treated with IFX combined with GC. We found that temperatures rapidly normalized, inflammatory indexes decreased, and vascular lesions gradually improved with IFX therapy. Additionally, IFX enabled a reduction in dose or discontinuation of GC. In cases 1-8, vascular lesions treated with IFX in the early stage began to resolve within 1.5-3 months. Most of the affected arteries recovered within 13 months, but some remained stenotic, with intimal thickening and uneven lumens that which did not resolve. In Case 9, some vascular lesions worsened during GC and MTX treatment, but the vascular lesions gradually recovered after initiating IFX. In Case 10, the coronary arteries and abdominal aorta improved, but other vascular lesions did not improve during three months of combination GC and tocilizumab therapy. Some vascular lesions gradually recovered after initiating IFX. In 6 infants with hypertension, blood pressure returned to normal after 3-8 months of IFX treatment, showing that treatment with IFX could lead to inactive disease status. IFX was effective, beneficial, and well-tolerated in all 10 TA infants. In Case 9, growth and development lagged behind normal growth and development, but after stopping glucocorticoids and starting IFX, growth and development improved.

Our study showed that IFX has a good safety profile for use in infants. During IFX treatment, only 1 infant had an allergic reaction, which was during the eighth infusion; other infusions were not associated with adverse events. No severe infections were diagnosed during treatment, consistent with previous reports[10, $13,20][21]$. Early application of IFX in cases 1-8 had no impact on growth and development.

Our study had limitations. Our case series had only 10 infants, and the follow-up time was relatively short. Therefore, studies of long-term effectiveness and safety of IFX for infantile TA need to include more infants and have longer follow-up times.

\section{Conclusions}

In infant-onset TA, early use of IFX can significantly and rapidly decrease inflammation and resolve clinical features of active disease, improve vascular lesions, and sustain remission for longer time than treatment with glucocorticoids and methotrexate. IFX enables dose reduction or discontinuation of GC, which promotes normal infant growth and development. IFX appears to cure some cases of infantile TA and induces a high rate of clinical remission.

\section{Abbreviations}

TA: Takayasu arteritis

IFX: infliximab

GC:glucocorticoid

MTX:methotrexate

CTA:CT angiography

TCZ: tocilizumab

WBC: leukocyte

HGB: hemoglobin

PLT: platelet

CRP: C-reactive protein

ESR: erythrocyte sedimentation rate

\section{Declarations}

\section{Acknowledgements}

The author thanks Dr. Lawrence Everett Rodewald in Chinese Center for Disease Control and Prevention for the revise and language editing to the manuscript.

\section{Funding}

No funding was received to carry out this work.

\section{Availability of data and materials}

Available upon request. 
Authors' contributions

KM participated inthe design of the study, compiled and analyzed the data and drafted themanuscript. LJMconceived the studyand revised the manuscript.ZD, XYJ and ZJparticipated in the design and coordination ofthe study, collected and analyzed data.LM participated in the design of the study, collectedand analyzed data. All authors read and approved the final manuscript.

Competing interests

The authors declare that they have no competing interests.

Consent for publication

Not applicable.

Ethics approval and consent to participate

The study was approved by the Ethical Committee of Children's Hospital Capital Institute of Pediatrics囚SHERLLM2021051『; Guardians provided written, informed consent for their infants.

\section{References}

1. Tombetti E, Mason JC: Takayasu arteritis: advanced understanding is leading to new horizons. Rheumatology (Oxford) 2019, 58(2):206-219.

2. Eleftheriou D, Varnier G, Dolezalova P, McMahon AM, Al-Obaidi M, Brogan PA: Takayasu arteritis in childhood: retrospective experience from a tertiary referral centre in the United Kingdom. Arthritis Res Ther 2015, 17:36.

3. Gudbrandsson B, Molberg O, Palm O: TNF inhibitors appear to inhibit disease progression and improve outcome in Takayasu arteritis; an observational, population-based time trend study. Arthritis Res Ther 2017, 19(1):99.

4. Stern S, Clemente G, Reiff A, Ramos MP, Marzan KA, Terreri MT: Treatment of Pediatric Takayasu arteritis with infliximab and cyclophosphamide: experience from an American-Brazilian cohort study. J Clin Rheumatol 2014, 20(4):183-188.

5. Li M, Sun XF, Xu YJ, Hou J, Zhang D, Chi Y, Zhu J, Kang M, Li SN, Su GX et al: [Infliximab in infantile Takayasu arteritis: a case report and literature review] Zhonghua Er Ke Za Zhi 2020, 58(12):1001-1005.

6. Ozen S, Pistorio A, lusan SM, Bakkaloglu A, Herlin T, Brik R, Buoncompagni A, Lazar C, Bilge I, Uziel Y et al: EULAR/PRINTO/PRES criteria for HenochSchonlein purpura, childhood polyarteritis nodosa, childhood Wegener granulomatosis and childhood Takayasu arteritis: Ankara 2008. Part II: Final classification criteria. Ann Rheum Dis 2010, 69(5):798-806.

7. Russo RAG, Katsicas MM: Takayasu Arteritis. Front Pediatr 2018, 6:265.

8. Agueda AF, Monti S, Luqmani RA, Buttgereit F, Cid M, Dasgupta B, Dejaco C, Mahr A, Ponte C, Salvarani C et al: Management of Takayasu arteritis: a systematic literature review informing the 2018 update of the EULAR recommendation for the management of large vessel vasculitis. RMD Open 2019 , 5(2):e001020.

9. Clemente G, Hilario MO, Len C, Silva CA, Sallum AM, Campos LM, Sacchetti S, Santos MC, Guariento Alves A, Ferriani VP et al: Brazilian multicenter study of 71 patients with juvenile-onset Takayasu's arteritis: clinical and angiographic features. Rev Bras Reumatol Engl Ed 2016, 56(2):145-151.

10. De Guerra VC, Hashmi H, Kramer B, Balluz R, Son MB, Stein D, Lieberman A, Zahra M, Abdul-Aziz R: A Case Report of Takayasu's Arteritis and Ulcerative Colitis in a Pediatric Patient with Chronic Recurrent Multifocal Osteomyelitis Successfully Treated with Infliximab: Diagnostic Clues in Disease Associations and Immune Dysregulation. Case Rep Rheumatol 2019, 2019:8157969.

11. Kierzkowska B, Lipinska J, Baranska D, Niewiadomska-Jarosik K, Biernacka-Zielinska M, Stanczyk J, Smolewska E: Takayasu's arteritis mimicking Kawasaki disease in 7-month-old infant, successfully treated with glucocorticosteroids and intravenous immunoglobulins. Rheumatol Int 2012, 32(11):3655-3659.

12. Aeschlimann FA, Barra L, Alsolaimani R, Benseler SM, Hebert D, Khalidi N, Laxer RM, Noone D, Pagnoux C, Twilt M et al: Presentation and Disease Course of Childhood-Onset Versus Adult-Onset Takayasu Arteritis. Arthritis Rheumato/2019, 71(2):315-323.

13. Liu H, Sun L, Upadhyaya RS, Chen Y, Ajoje 00: Case report: Takayasu arteritis in a 3-month-old Chinese girl. Medicine (Baltimore) 2018 , 97 (41):e12637.

14. Pavic R, Blazekovic R, Divkovic D, Marjanovic K, Sipl M: Aggressive progression of Takayasu's arteritis in infancy: a case report. Acta Clin Croat2019, 58(3):535-539.

15. Singh N, Hughes M, Sebire N, Brogan P: Takayasu arteritis in infancy. Rheumatology (Oxford) 2013, 52(11):2093-2095.

16. Higaki R, Miyazaki A, Tajiri Y, Shoji M, Saito S, Yoshimura SI, Miki N, Hatta K, Doi H: Continuous infusion of lipo-prostaglandin E1 for Takayasu's arteritis with heart failure in an 11-month-old baby: a case report. J Med Case Rep 2018, 12(1):266.

17. Goel R, Sathish Kumar T, Danda D: Childhood-Onset Takayasu Arteritis (c-TA): Current and Future Drug Therapy. Paediatr Drugs 2019, 21 (2):81-93.

18. Osman M, Pagnoux C, Dryden DM, Storie D, Yacyshyn E: The role of biological agents in the management of large vessel vasculitis (LVV): a systematic review and meta-analysis. PLoS One 2014, 9(12):e115026.

19. Mekinian A, Comarmond C, Resche-Rigon M, Mirault T, Kahn JE, Lambert M, Sibilia J, Neel A, Cohen P, Hie M et al: Efficacy of Biological-Targeted Treatments in Takayasu Arteritis: Multicenter, Retrospective Study of 49 Patients. Circulation 2015, 132(18):1693-1700. 
20. Barra L, Yang G, Pagnoux C, Canadian Vasculitis N: Non-glucocorticoid drugs for the treatment of Takayasu's arteritis: A systematic review and metaanalysis. Autoimmun Rev 2018, 17(7):683-693.

21. Brunner J, Feldman BM, Tyrrell PN, Kuemmerle-Deschner JB, ZimmerhackI LB, Gassner I, Benseler SM: Takayasu arteritis in children and adolescents. Rheumatology (Oxford) 2010, 49(10):1806-1814. 